\title{
The Cultural Analysis of Disaster
}

\author{
Holm, Isak Winkel
}

Published in:

The cultural life of catastrophes and crises

Publication date:

2012

Citation for published version (APA):

Holm, I. W. (2012). The Cultural Analysis of Disaster. In C. Meiner, \& K. Veel (Eds.), The cultural life of catastrophes and crises (pp. 15-32). De Gruyter. Concepts for the Study of Culture Vol. 3 


\title{
The Cultural Life of Catastrophes and Crises
}

\author{
Edited by \\ Carsten Meiner and Kristin Veel
}

De Gruyter 


\title{
The Cultural Analysis of Disaster
}

\author{
ISAK WINKEL HOLM
}

"What hit the Mississippi Gulf Coast was a natural disaster, a hurricane, pure and simple. The flooding of New Orleans was a man-made catastrophe, a federal fuck-up of epic proportions, and decades in the making." Creighton Bernette, a choleric university professor, played by John Goodman, works himself into a rage in the currently running $\mathrm{HBO}$ drama Treme about post-Katrina New Orleans. Bernette's fit of anger is, in fact, two distinct fits of anger in close succession of each other. The first fit is directed against a federal government unable to construct a reliable flood protection system. As he explains to a $\mathrm{BBC}$ reporter, "The floodgates failed, the canal walls failed, the pumps failed, all of which was supposedly built to withstand a much greater storm." His second fit of anger is directed against the British reporter himself, who insults New Orleans by calling its food provincial and its music passé. Bernette sums up the reporter's remarks: "[...] provincial, passé, hate the food, hate the music, hate the city; what the fuck you doing down here you fucking limey vulture motherfucker?" and then, accordingly, throws the reporter's microphone into the canal and lunges after the camera.

The two directions of Bernette's anger highlight the two most important themes in contemporary disaster research, both of which were dramatically underscored by Hurricane Katrina. The initial fit of anger is about the man-made character of a calamity which was not simply a biophysical phenomenon but also a "federal fuck-up of epic proportions." The second fit of anger is about the media-borne character of a calamity caused to a large decree by the severe misrepresentations and misunderstandings of the city of New Orleans by federal and international media, behaving less like sober eye-witnesses and more like vultures preying on death and suffering. On the following pages, I shall give a brief overview over the contemporary cultural analysis of disaster, highlighting how this rather new field of research tackles the double challenges of the man-made and the media-borne character of disaster. 


\section{Man-made Disasters}

Since disaster research emerged as a sub-discipline of sociology, its focus is the economic, political and social infrastructure of society. According to the classical definition of Charles Fritz, "A disaster is an event concentrated in time and space, in which a society or one of its subdivisions undergoes physical harm and social disruption, such that all or some essential functions of the society or subdivisions are impaired" (Fritz). As climate change has replaced the atomic war in the cultural imagination of disaster, it has become more and more meaningless to think of disasters as sudden concentrated events disrupting society from the outside. In an atmosphere increasingly shaped by human agency, disasters are no longer purely 'natural' but, rather, hybrid and at least halfway anthropogenic. Even the hurricane 'pure and simple' hitting the Mississippi Gulf Coast on August 29th 2005 was, to some degree, man-made because increasing hurricane intensity is caused by a rise in sea surface temperature due to global warming. The German philosopher Peter Sloterdijk, who is always good at inventing new words, describes modern human beings as "atmosphere designers" and "weather co-producers” (Sloterdijk, Schäume 171).

Accordingly, during the last twenty years, disaster research has shifted its focus from the event impacting on human society towards human society contributing to the disaster. This shift of focus has led to important conceptual distinctions between "hazard", "vulnerability" and "disaster". The hazard is the hurricane pure and simple - the hurricane (or the earthquake, the volcano, the drought, the spillage of hazmat, etc.) as an agent hitting human society from the outside. Vulnerability is, in Creighton Bernette's pithy words, a concept for the ensemble of "federal fuck-ups" - human society's own contribution to disaster, or at least to the severity and duration of disaster. What is at stake here are the "pre-disaster conditions" determining how a given society is unable to cope with a hazard (Oliver-Smith and Hoffman 4). The disaster, finally, is a concept used today for the entire phenomenon with its non-human as well as human dimensions, its biophysical and federal factors. In other words, the vulnerability perspective of contemporary disaster research suggests interpreting catastrophes as if they were in fact crises: not as sudden exogenous calamities but, rather, as endogenous results of human agency invisibly working their effect slowly over a period of years. As Bernette explains, the disaster was "decades in the making."

Next to Haiti, New Orleans is a textbook example of disaster vulnerability due to its location below sea level and its severe social problems. Bernette again: "Down here, in this city of misrule, we are always our own worst enemy." In The Sociology of Katrina, J. Steven Picou follows Bernette's interpretation of the event: 
As the levees breached and floodwaters inundated 80 percent of the city, the failure of engineered, human-made levees revealed a critical second characteristic of Katrina's catastrophic impacts, that is, the failure of human technology and the collapse of an engineered levee system designed to protect residents. Indeed, the 'complexity' of Katrina does not end with the failure of levee technology. Katrina was also a massive contamination event, with oil, pesticides, fertilizers, and numerous other hazardous and toxic wastes being contained in the floodwaters and migrating throughout New Orleans, St. Bernard Parish, the lower Ninth Ward, and the Lakeview Area. (Picou 2)

According to Picou, the complexity of Katrina - the 'Katrina difference' has "reawakened the sociological imagination for many", prompting a "paradigm shift" towards the vulnerability perspective in contemporary disaster research. The changing nature of risk in the modern world has demonstrated the shortcomings of the classical distinction between natural and manmade disaster, forcing researchers to imagine disaster through the help of the "natural-technological" disaster model, the so-called na-tech disaster.

\section{Media-borne Disasters}

Classical disaster research has positivist inclinations insofar that it focuses on the brute scientific facts of the hazard itself or, alternatively, on the brute sociological facts of the afflicted human society. From this perspective, vulnerability is first and foremost a question of the economic, political and social infrastructure of a given society. Often, even the description of human reactions to the collapse of social infrastructure is kept in strictly positivist terms, focusing solely on the frequency of PTSD (post-traumatic stress syndrome) in the post-disaster population. The recent decade, however, has seen a growing recognition of the importance of the cultural framing of disaster. According to this "cultural turn" in sociological disaster research (Webb), not only the physical and institutional but also the cultural infrastructure of a society play a major role in shaping disaster by determining how it is interpreted by human beings.

Bernette's anger at the TV crew is well founded. When Katrina made landfall, news media sources broadcast the dramatic stories of a city on the brink of collapse. On September $3^{\text {rd }}$, even The New York Times wrote "America is once more plunged into a snakepit of anarchy, death, looting, raping, marauding thugs, suffering infrastructure, a gutted police force, insufficient troop levels, and criminally negligent government planning." As the water receded a week later, it appeared, however, that the images of a collapsing civilisation were fictitious: there were no piles of bodies, no 
documentation to back the stories of babies taken from their parents' arms and raped. According to sociological disaster researcher Kathleen Tierney, the media's dramatic images from New Orleans played an important role in the authorities' miserable disaster management:

Initial evidence suggests that the media's relentless adherence to disaster myths and to frames emphasising civil unrest and urban insurgency, along with the strategic response measures these reports justified, had a number of immediate negative consequences. [...] Distorted images disseminated by the media and public officials served to justify calls for greater military involvement in disasters. (Tierney, Bevc and Kuligowski)

The quote above is taken from Tierney's first paper on Katrina, published only six months after the hurricane under the telling title "Metaphors Matter: Disaster Myths, Media Frames and Their Consequences in Hurricane Katrina". The images circulated by American media were metaphors because they were based on a fundamental metaphorical transport from war to disaster; Katrina was not a war, but it was seen as war and insurgence (Tierney and Bevc). Nonetheless, these distorting metaphors did matter because they had important effects on the ground. Three days after the collapse of the levees, the Governor of Louisiana and the Mayor of New Orleans suspended lifesaving operations and ordered emergency responders to concentrate on arresting looters and deterring crime. In total, 63,000 troops from the National Guard were deployed in the so-called "war zone" of downtown New Orleans, many with fresh combat experience from Iraq. In this large military operation, unprecedented on American soil, the citizens of New Orleans were regarded not as disaster victims but as "urban insurgents". Thus, Hurricane Katrina was a natural disaster and a cultural disaster at the same time - an example of cultural framing of a disaster with disastrous consequences.

Even a commentator as shrewd as the Slovenian philosopher Slavoj Žižek was trapped by the dramatic media framing of Katrina when he, a short while after the flooding, compared New Orleans with Kabul, Baghdad, Mogadishu and Freetown:

The US authorities, this universal policeman endeavoring to control the threats to peace, freedom and democracy all around the globe, lost control of a part of the metropolis itself: for a couple of days, the city regressed to a wild preserve of free looting, killing and rapes, it became the city of the dead and dying, a postapocalyptic Zone in which what Giorgio Agamben called homini sacer - those excluded from the civil order - wander around. (Žižek, "Some")

When Žižek reprinted his essays on Katrina in his 2008 book On Violence, he corrected his initial misunderstanding by adding a single word: "For a few days, New Orleans apparently regressed to a wild preserve of looting, 
killing and rape" (Žižek, Violence 79 my italics). Nevertheless, Žižek makes an important point by highlighting the "fictional presence" of disasters on $\mathrm{TV}$ and theatre screens long before they happen in real life:

Something happened that we've already seen - where? The scenes we saw on the TV news in the last days cannot but recall a whole series of real life, media and cultural phenomena. [...] It DID already happen in the US: in Hollywood, of course, the Escape from ... series (Escape from New York, Escape from Los Angeles), in which a US megalopolis is cut off from the domain of public order and criminal gangs take over. [...] Something that we were only aware of as a fictional presence on TV and theatre screens, brutally entered our reality (Žižek, "Some")

In the case of Hurricane Katrina, American media did not depict the real disaster; they replayed a version of our collective imagination of disasters as we know them from Hollywood movies and other kinds of disaster fiction. As Žižek famously wrote about the terrorist attacks on World Trade Centre, American disaster fiction had already imagined an unimaginable event like that: "the unthinkable which happened was the object of fantasy, so that, in a way, America got what it fantasized about, and that was the biggest surprise" (Žižek, Welcome 16).

Tierney and Žižek point out the importance of the cultural imagination of disaster. Disasters are media-borne because they are primetime news in the media but also, in a wider sense, because they are culturally mediated, filtered through society's collective repertoire of metaphors, images, narratives and concepts that governs how we make sense to senseless disasters. Today, this symbolic infrastructure is, first of all, created by the classical Hollywood disaster movies mentioned by Tierney and Žižek. But of course, the "fictional presence" of disaster has deeper historical roots in earlier disaster fiction, in historical accounts of famous disasters, in popular disaster panoramas, and in the religious ideas and narratives.

\section{Cognitive Scheme}

The "cultural turn" in sociological disaster research is mirrored by a "social turn" in cultural studies. As Frank Kermode wrote in The Sense of an Ending (1967), the main object of his erudite cultural history of the apocalypse is "making sense of some of the radical ways of making sense of the world" (Kermode 29). Remarkably, however, Kermode abstains from discussing our ways of making sense of real life disasters; he restricts himself to the ways of sense-making studied by classical humanistic disciplines such as literary studies and philosophy of history. The recent decade, however, has seen a fast-growing interest in our ways of making sense of real life disas- 
ters. According to this "social turn" in the cultural analysis of disaster, our shared disaster images cannot be enclosed within the sphere of fine arts and high theory; they play a crucial role outside novels, essays, movies, and operas by governing how human beings manage and imagine disasters.

The emerging cultural analysis of disaster is a cross-disciplinary field of study in which there are as many theoretical approaches as there are humanistic disciplines and theoretical schools. Across the borders of academic disciplines, however, the recent explorations of the cultural imagination of disaster tend to agree on analyzing recurring patterns of imagination. The common object of study is the deep grammar of Western disaster imagination. I would suggest the term "cognitive schemes" for the mental models allowing us to think about disasters and to deal with them pragmatically. With Ernst Cassirer's classical term, we have to do with the repertoire of "symbolic forms" that makes up the symbolic infrastructure governing how we cope with disasters. It is striking how overlapping or synonymous names for cognitive schemes play important methodological roles in contemporary explorations of the cultural imagination of disaster. The scholars analyse "tropes" and "key structuring metaphors" (Garrard 14), "disaster myths" (Tierney, Bevc and Kuligowski), "mental and institutional mechanisms at work when people imagine things" (Clarke 63), "symbolic forms" (Beck, "Living" 332), historical "ways of managing and imagining disasters" (Rozario 2), "forms of collective representation" governing the "symbolic management" of disasters (Walter 14, 25), "templates" and "cultural tools" (Heise 63, 138), "frames of interpretation" (Schenk 12), "collective figures of interpretation" (Welzer, Soeffner and Giesecke 12) and, once again, "myths" (Hulme).

In these recent contributions to the cultural analysis of disaster, however, the cultural repertoire of cognitive schemes is only gestured vaguely at, and not developed theoretically. Thus, the vastly growing field of research is methodologically flawed in so far as it fails to make clear what kind of object it analyses. Two theoretical models underlie most of what is written today about the cultural imagination of disaster:

Ideology. By using the concept 'disaster myths', Tierney places herself in the theoretical framework of the Marxist critique of ideology. On the one hand, she posits the mythos of the distorted popular imagination, on the other, the logos of the social sciences, thus offering an objective and reliable representation of social reality. In the classical study Response to Disaster: Fact Versus Fiction and Its Perpetuation (1994), the American sociologist Henry Fischer makes a similar distinction between ideologically charged 'fictions' about post-disaster looting and chaos in the popular imagination and the sober 'facts' supplied by the social sciences. The theoretical framework of the critique of ideology is well-suited to Tierney's description 
of the severe malfunctioning of American media and authorities, but it becomes somewhat one-dimensional when the aim is to develop a broader understanding of the cultural imagination of disaster. Metaphors not only matter as an ideological distortion of social reality, but also they matter as a cognitive condition of possibility for managing and imagining social life. Shared disaster images are not just a disposable veil that hides the reality of disasters from us; they are also, as it were, a necessary rug, a cultural footing on which we stand when we try to cope with disasters.

Discourse. Another dominating theoretical framework in the contemporary cultural analysis of disaster is the Foucauldian discourse analysis. Many scholars describe their subject matter as a "disaster discourse" (Lauer; Rozario). In Foucault, however, "discourse" is a term ascribed to disciplined scientific language that organises and creates its object in a certain way. Volcanology, risk management, insurance science and psychological trauma theories are discourses in this Foucauldian sense, but the cognitive schemes of the cultural imagination of disaster do not necessarily have the status of theoretical concepts; rather, they are non-theoretical images, inchoate and diffuse notions and narratives. Moreover, cognitive schemes are not endemic to specific disaster discourses but migrate across the borders between academic disciplines involved in disaster research and across the borders between the academic disaster research and the popular disaster imagination.

\section{The Social Imaginary of Disaster}

I would suggest the concept of the social imaginary as a theoretical framework for the cultural imagination of disaster. In the past decade, this concept has been developed in political philosophy and anthropology as a phrase for the way a group of people imagine their life together, their implicit map of social space or, to use a more up-to-date metaphor, their social GPS enabling them to orient themselves in society. According to the definition given by the political philosopher Charles Taylor, the social imaginary is a term for the way in which we collectively imagine our social life:

What I'm trying to get at with this term is something much broader and deeper than the intellectual schemes people may entertain when they think about social reality in a disengaged mode. I am thinking rather of the ways in which they imagine their social existence, how they fit together with others, how things go on between them and their fellows, the expectations which are normally met, and the deeper normative notions and images which underlie these expectations. (Taylor, Modern Social 23) 
Charles Taylor suggests the term "social imaginaries", whereas Arjun Appadurai writes about "social imagination" (Appadurai) and Jacques Rancière about the "distribution of the sensible" (Rancière). The theoretical background is made up, first of all, by Cornelius Castoriadis' concept of a society's "imaginary institution" (Castoriadis) and Benedict Anderson's notion of "imagined communities" (Anderson). Certainly, the recent concept of the social imaginary overlaps in many ways with the classical concepts of ideology and discourse, but it is not synonymous with these concepts. As opposed to an ideology, a social imaginary is not necessarily a distortion or a misperception of social reality, as it can also be vital to opening up alternative ways of understanding and organising societies. Interpreted as a part of the social imaginary, disaster images are not just a smokescreen hiding the hard facts of disaster, but also a cultural tool enabling human beings to make sense of a disaster. As opposed to a discourse, on the other hand, a social imaginary is not a sociological theory or a scientific language; instead, first of all, it is a much broader pre-theoretical and non-verbal background understanding of the order of things, shared by scientists and laymen alike. Interpreted as a part of the social imaginary, disaster images are, precisely, images.

As Creighton Bernette's double anger demonstrates, catastrophes and crises live a double cultural life as both man-made and media-borne, i.e. humans create disasters and they create images of disasters. The concept of the social imaginary is helpful in giving a theoretical account of these two cultural lives.

First, the man-made dimension forces us to view the cultural imagination of disaster as contextualised. Cognitive schemes governing the way we manage and imagine disaster are a subset of a much larger and far more complex social imaginary. The reason why this point needs stressing is that, within the field of the cultural analysis of disaster, there is a tendency to detach the standard repertoire of disaster images from all other images of social life. Such a narrow perspective on the cultural imagination of disaster focuses on the event itself in a way similar to that of a Hollywood movie. In a classical disaster movie, you have to watch approximately fifteen minutes of "normalcy" at the beginning of the movie before the plot gets around to depicting the violent impact of the hazard, the crumbling buildings, the looting hordes and, most often, the heroic deeds that put the world right again. However, the cultural imagination of disaster is not just a series of dramatic images of the hazard itself but is also, on a deeper level, a much broader background understanding of the vulnerability or resilience of the social order. In Charles Taylor's words, what is at stake is a sense of how we fit together with others, of how things go on between us and our fellows, and of what we can expect in times of stress. In order to 
understand the cultural imagination of disaster, we therefore have to focus on how it gears into other modes of imagining social life.

In the TV-series Treme, for instance, we very rarely see images of the hurricane itself. Instead, the series depicts the much more undramatic aftermath, starting three months after the flooding, where the residents of New Orleans struggle to rebuild their homes, restaurants, jazz orchestras and Mardi Gras Indian groups. In this case, the cultural imagination of disaster pertains to the way New Orleanians feel loyalty or disloyalty towards their community, the way they fight for or give up their way of life and the way they trust or mistrust legal and political authorities. In fact, a considerable amount of disaster fiction does not represent the hazard itself but, rather, a social world seen in the light of an impending hazard, some of the most famous being Bertolt Brecht's Rise and Fall of the City of Mahagonny, Robert Altmann's Short Cuts and Andrey Tarkovsky's The Sacrifice.

Second, the media-borne dimension forces us to view the cultural imagination of disaster as constitutive. Disaster images not only represent disasters, but also they produce disasters; they not only offer a description of past disasters but also function as a script for the social practices before, during and after disasters. Metaphors matter, in Tierney's words, while Žižek makes a similar point when writing that the false media reports about rape and looting in New Orleans "were not merely words, they were words which had precise material effects" (Žižek, Violence 84). This is an important point, first of all for epistemological reasons. In the social sciences, there is a tendency to approach disaster as a brute reality generating a set of ideas, reactions or symptoms of PTSD in people's heads. This kind of approach creates a sharp epistemological divide between object and subject, between brute facts and beliefs. However, this subject-object divide is not helpful when dealing with disasters which are not just biophysical events (hazards) but also involve the whole surrounding network of social practices. In Charles Taylor's famous phrase, man is a "self-interpreting animal" (Taylor, Philosophical 26), and the same goes for man as disaster victim in that the way human beings deal with disasters is dependent on the way they interpret them and is, accordingly, framed by the social imaginary underlying this interpretation.

Treme is not a story about the impact of a disaster; it is, first of all, a story about the interpretation of a disaster. The way the characters in the series act in the aftermath of Hurricane Katrina is contingent upon their conflicting ways of making sense of the messy situation. These interpretations do not have the epistemological status as somebody's beliefs about Hurricane Katrina; instead, they play a constitutive role in the painstakingly slow rebuilding of post-disaster New Orleans. In this sense, the TV series is to be seen as what sociologists and political philosophers have 
dubbed "double hermeneutics" (Giddens 12; Habermas 159 ): a second order interpretation of the way people interpret the world in which they act. The same goes for many important works of disaster fiction. Heinrich von Kleist's "The Earthquake in Chile" from 1806, for instance, the founding work of modern disaster fiction, is a short story about the earthquake in Santiago in 1647, but first and foremost it is a story about human beings' fatal ways of making sense of the earthquake.

\section{Cultural Forms of Disaster}

Since the paradigmatic 1755 Lisbon earthquake, as several disaster scholars have noted, the repertoire of cognitive schemes structuring the cultural imagination of disaster in the Western world has, in fact, been surprisingly small and unexpectedly stable. Therefore, the 'cultural turn' in disaster research is also a 'cultural historical turn'. In this section, I will give a brief historical overview of the most prominent disaster images in the cultural history of the Western world, ordered after scale: from the individual human being via the political community and its natural surroundings to problems of cosmological and theological size.

The sublime. When we perceive disaster through the cognitive scheme of the sublime, we focus on the violent sense experience overwhelming the observer who, stricken with terrified dumbness and bodily stupor, experiences a masochistic blend of pain and pleasure. The theory of the sublime was developed in eighteenth century aesthetic theory wherein earthquakes and volcanoes were cited as default examples of the sublime sense experience. Classical interest in the sublime was based on the Roman rhetorician Longinus (or Pseudo-Longinus) who, in On the sublime, wrote about the violent sight of the erupting volcano Etna. Immanuel Kant's chapter on the sublime ("das Erhabene") from Critique of the Power of Judgment (1790) is a sum of the eighteenth Century theory of the sublime as well as one of the most famous pieces of disaster discourse of the century. In the cultural imagination of disaster, this cognitive scheme is at work whenever there is talk about the terrible, awe-invoking beauty of disasters as a matter of aesthetic pleasure or displeasure. In cultural studies, this mode of disaster imagination more or less disappeared in the nineteenth century, but experienced a short and intense revival in the 1980s caused, initially, by the Kant readings of Jean-Francois Lyotard (Blumenberg; Lyotard "The Sublime", Heidegger; Ray).

Trauma. When we perceive disaster through the cognitive scheme of the trauma we focus on the wound (in Greek $\tau \rho \alpha \tilde{v} \mu \alpha$, "trauma") that the violent event inflicts on the human psyche. The theory of trauma was de- 
veloped within the field of psychology and psychoanalysis in the wake of railway accidents of the nineteenth century and the industrialised warfare of the twentieth (Micale and Lerner; Schivelbusch). In the cultural imagination of disaster, this cognitive scheme is active whenever disasters are approached as a matter of an individual human being's psychic health threatened by a 'shock' or 'post-traumatic stress syndrome'. In cultural studies, this way of making sense of disasters was suggested by Shoshana Felman and Dori Laub in their important 1992 book on Holocaust testimonies, Testimony. Crises of Witnessing in Literature, Psychoanalysis, and History. Today, trauma is beyond doubt the dominant cognitive scheme in the cultural analysis of disaster (Caruth, Trauma, Unclaimed; Felman; Felman and Laub; Foster; Kaplan; LaCapra History, Writing; Weine).

State of emergency. When we perceive disaster through the cognitive scheme of the state of emergency or state of exception, we focus on the breakdown of legal and normative structures caused by the disaster. Legal theory pertaining to the state of emergency can be traced back to Roman law, according to which the Roman constitution could be suspended for up to six months if the republic was threatened (Dyzenhaus; Ferejohn; Gross and Nâi Aolâain; Lazar; Sarat, Douglas and Umphrey). In the cultural imagination of disaster, the state of emergency is a frequent cognitive scheme in popular disaster fiction. Here, images of looting hordes and other forms of asocial behaviour raise the question of social chaos supposedly hiding under a thin layer of civilisation. In recent cultural studies, this disaster scheme has played a vital role, most often inspired by Giorgio Agamben's writings about homo sacer and naked life in the state of exception (Agamben, Homo, State; Neyrat; Žižek, Violence).

Risk. When we perceive disaster through the cognitive scheme of risk, we focus on the rational calculations of the probability of a disastrous event. The theory of risk has its roots in seventeenth-century mathematics and the application of the calculus of probability on a market economy. In the cultural imagination of disaster, the cognitive scheme of risk is relevant whenever we address disasters in terms of chance and precautionary principles. Cultural studies have contributed by examining how the shared imaginations of risk influence the rational calculations of risk. Classical work here comes from anthropologists Mary Douglas and Aaron Wildavsky's Risk and Culture (1982) about the popular patterns of risk perception and how they distort the way people feel exposed to risks (Douglas and Wildavsky). This work has inspired and provoked a host of contemporary explorations of "risk culture" (Beck, Risk, Weltrisikogesellschaft; Clarke; Dupuy, Pour; Virilio).

Imbalance. When we perceive disaster through the cognitive scheme of imbalance and sustainability, we focus on the imbalance between human 
and biophysical systems causing disaster. The theory of disaster as imbalance was developed by the ecological movement, which gained momentum in the second half of the twentieth century. In cultural studies, this way of imagining disaster has been the platform for so-called ecocriticism, most recently and most fruitfully utilised in Ursula K. Heise's Sense of Place and Sense of Planet from 2009 but see also (Frederick Buell; Lawrence Buell; Garrard; Gifford; Heise; Sloterdijk, Sphären).

Apocalypse. When we perceive disaster through the cognitive scheme of the apocalypse, we focus on it as the end of the world as we know it. This way of making sense of disasters has theological roots in the Book of Revelation (Lifton). In cultural studies, an investigation of the apocalyptic imagination was suggested by Frank Kermode in his aforementioned Sense of an Ending from 1967, a groundbreaking study followed by a host of more recent analyses of the apocalyptic images at work in fiction (Frederick Buell; Böhme; Davis, Ecology, Dead; Derrida; Friedrich; Wagar; Wojcik).

Blessing in disguise. When we perceive disaster through the cognitive scheme of the blessing in disguise, we focus on the way disasters prepare the ground for new growth. This cognitive scheme, maybe just a subspecies of the apocalypse scheme, did not take shape as a theoretical concept but, rather, in the theological and mythological imagination of disaster as 'world fire' and as 'purification'. Recently, cultural studies have explored how this cluster of disaster images governs the American imagination of modernisation and economic reorganisation, most importantly in Kevin Rozario's The Culture of Calamity: Disaster and the Making of Modern America and in Naomi Klein's The Shock Doctrine.

Theodicy. When we perceive disaster through the cognitive scheme of a theodicy, we focus on a god (or some god-like agent) who can be held responsible for the whole event. The theoretical concept of the theodicy became an indispensable part of disaster discourse after the 1755 earthquake in Lisbon. The cultural shockwaves of the paradigmatic quake vitalised the artificial word 'theodicy', at the time just coined by the German philosopher Gottfried Leibniz by combining theos and dike, the Greek words for God and justice. Si Deus est, unde malum? If God is almighty and good, how can the world be full of evil and meaningless events like earthquakes? Since Jean-Jacques Rousseau, this large-scale theological such as question has delivered underlying imagery for the sociological discussion of vulnerability (Dynes). In the cultural imagination of disaster, this model is at work whenever disasters - at least once in every Hollywood disaster movie - prompt a question about our trust in the basic goodness of the world or that of society. In cultural studies, Susan Neiman has offered a brilliant history of the theodicy question in Evil in Modern Thought: An Alterna- 
tive History of Philosophy. Other, less panoramic explorations of the theodicy approach to disaster can be found in (Dupuy, Petite; Holm; Kendrick; Lauer; Mercier-Faivre and Thomas).

This is in no way a closed list but, rather, a selection of prominent cognitive schemes and their original context in aesthetics, psychology, law, etc. As part of the social imaginary, however, these ways of making sense of disasters are not endemic to their original contexts but migrate across the borders between specific discourses as well as between theoretical discourse and the wider field of the cultural disaster imagination. Therefore, it is not sufficient to explore one single cognitive scheme, as most individual scholars and research communities in the field tend to do, focusing on either the sublime or the trauma or the theodicy, etc. A comprehensive cultural analysis of disaster must be able to map the entire field of contemporary disaster imagination.

\section{Disaster Fiction}

In Treme, we learn that Creighton Bernette has troubles finishing a novel about the Great Mississippi Flood of 1927, feeling that fiction writing is inconsequential, unimportant and academic in the light of the real life hurricane. Instead, he lets out his anger on YouTube, directly and with instant feedback from his fellow citizens. Bernette's arguments for giving up the novel raise the question of the function of disaster fiction. On the one hand, fictional representations of disasters in novels, TV-series, movies, cartoons, documentaries, operas and computer games are a part of the wider field of the cultural imagination of disaster. Fiction draws on the same limited repertoire of disaster images underlying science, politics, law, religion, etc. On the other hand, however, works of fiction are one step further away from real life disasters than, for instance, national news bulletins and political speeches and are therefore, at least according to Bernette, more inconsequential.

In contemporary cultural studies, there is a strong tendency to explain the function of disaster fiction as a working through of traumatic experiences. Today, after Hurricane Katrina and the plethora of post-9/11 novels, research in disaster fiction is dominated by the cognitive scheme of the trauma, much in the same way as the idea of the sublime dominated the aesthetics of disaster in the eighteenth century. The undeniable strength of the trauma approach is due to the way it underlines the unknown and unspeakable character of a sense experience disrupting all rational and linguistic patterns of understanding. As noted earlier, modern sociological disaster research transforms catastrophes into crises and, hence, into events 
that can be explained by giving an account of the features that make a society vulnerable. If we want to show how disasters are, in fact, "decades in the making", as Bernette claimed, we tend to focus on their understandable, meaningful and, as it were, human side. On the contrary, the concept of trauma insists on the disaster's brutal meaninglessness that runs counter to any rational explanation. In other words, the cognitive scheme of the trauma is an important memento of the profound incomprehensibility of disasters.

However, cognitive schemes have their strengths and their weaknesses. Imagining disasters as traumas is not very helpful when the task is to understand their man-made and media-borne characters. As for man-made characters, the methodological focus on the psychology of the individual renders the trauma approach unable to grasp the context of collective and systemic mechanisms through which human beings contribute to disaster. Accordingly, the federal nature of the "fuck-up" tends to disappear. To put it polemically, the only image of collective human life available within the theoretical framework of the trauma is the total count of individual cases of PTSD. As for the media-borne character of disaster, on the other hand, the trauma approach invites us to understand a work of disaster fiction as a representation of a sense experience - an impossible, distorted and belated representation of an unspeakable $X$, undeniably, but still a representation of a prior event. The sharp epistemological divide between object and subject, between the brute unspeakable fact and the blurred fictional representation of it, makes it difficult to account for the constitutive character of the cultural imagination of disaster. To also put this point polemically, the cognitive scheme of the trauma makes us forget that disasters are not brute facts to be processed in works of disaster fiction but, rather, are modified facts formatted by the cultural frameworks through which we perceive them.

I am not arguing that we should give up the notion of trauma; I am merely making the point that any cognitive scheme, even the currently successful trauma scheme, generates its own special pattern of blindness and insight. Theoretical models only have limited utility. Imagining disaster as trauma is not particularly relevant when we interpret a work of disaster fiction such as the TV-series Treme, for instance. The focus of the series is not the fictional characters' psychic health but their social imaginaries on which the slow rebuilding of New Orleans depend. Likewise, classic works of disaster fiction such as Richard Wagner's Twilight of the Gods and Isak Dinesen's "The Deluge at Norderney" from Seven Gothic Tales cannot be viewed as stories of individual human beings working through traumatic experiences. This kind of disaster fiction does not function as a fictional hospital in which individual traumatic experiences of disaster can be cured; instead, it acts as a fictional laboratory in which collective modes of imagining society can be explored. 
The double 'cultural turn' in modern disaster research - demonstrated by Bernette's twin fits of anger - underlines the dual importance of a cultural analysis of disaster. Current debates on impending climate disasters, for example, often turn into battles about hard facts: the rise of sea levels in centimetres, the melting of glaciers in degrees Celsius. As a part of a global decision process, however, these facts are not naked but dressed up in social practices and social imaginaries that determine how we cope with them or fail to cope with them. In the terms of Bruno Latour, disasters are quasiobjects which are "much more social, much more fabricated, much more collective than the 'hard' parts of nature" (Latour 55). The task of a cultural analysis of disaster is to explore the cultural forms through which the hard facts of disasters make sense to us. In this task, works of disaster fiction such as Treme are not inconsequential but highly consequential, not just as testimonies representing the hard facts of disaster, but also as testing grounds for the collective cognitive schemes we use to fabricate an image of disaster. The cultural imagination of disaster is not just a repertoire of immobile archetypes, but also, fortunately, a way of actively revealing and reworking the way we make sense of it.

\section{References}

Agamben, Giorgio. Homo sacer: Sovereign Power and Bare Life. Stanford, California: Stanford University Press, 1998.

-. State of Exception. Chicago: University of Chicago Press, 2005.

Anderson, Benedict. Imagined Communities: Reflections on the Origin and Spread of Nationalism. London: Verso, 1983.

Appadurai, Arjun. Modernity at Large: Cultural Dimensions of Globalization. University of Minnesota Press, 1996.

Beck, Ulrich. Risk Society: Towards a New Modernity. London; Newbury Park, California: Sage Publications, 1992.

—. "Living in the World Risk Society". Economy and Society 35.3 (2006): 329-345.

-. Weltrisikogesellschaft: auf der Suche nach der verlorenen Sicherheit. Frankfurt am Main: Suhrkamp, 2007.

Blumenberg, Hans. Schiffbruch mit Zuschauer: Paradigma einer Daseinsmetapher. Frankfurt am Main: Suhrkamp, 1979.

Buell, Frederick. From Apocalypse to Way of Life: Environmental Crisis in the American Century. New York: Routledge, 2003.

Buell, Lawrence. The Future of Environmental Criticism: Environmental Crisis and Literary Imagination. Malden, MA: Blackwell Pub, 2005.

Böhme, Hartmut. "Vergangenheit und Gegenwart der Apokalypse". Natur und Subjekt. Frankfurt am Main, 1998.

Caruth, Cathy. Trauma Explorations in Memory. Baltimore: Johns Hopkins University Press, 1995. 
-. Unclaimed Experience: Trauma, Narrative, and History. Baltimore: Johns Hopkins University Press, 1996.

Castoriadis, Cornelius. L'institution imaginaire de la societé. Paris: Éditions du Seuil, 1975.

Clarke, Lee. Worst Cases: Terror and Catastrophe in the Popular Imagination. Chicago: The University of Chicago Press, 2006.

Davis, Mike. Ecology of Fear: Los Angeles and the Imagination of Disaster. New York: Metropolitan Books, 1998.

-. Dead Cities, and Other Tales. New York: New Press 2002.

Derrida, Jacques. Psyche: Inventions of the other. Stanford: Stanford University Press, 2007.

Douglas, M., and Wildavsky, A. B. Risk and Culture: an Essay on the Selection of Technical and Environmental Dangers. Berkeley: University of California Press, 1982.

Dupuy, Jean-Pierre. Pour un catastrophisme éclairé: quand limpossible est certain. Paris: Seuil, 2002.

—. Petite métaphysique des tsunamis. Paris: Seuil, 2005.

Dynes, Russell R. "The Dialogue between Voltaire and Rousseau on the Lisbon Earthquake: The Emergence of a Social Science View". International Journal of Mass Emergencies and Disasters 18 (2000).

Dyzenhaus, David. The Constitution of Law: Legality in a Time of Emergency. Cambridge: Cambridge University Press, 2006.

Felman, Shoshana. The Juridical Unconscious: Trials and Traumas in the Twentieth Century. Cambridge, Mass.: Harvard University Press, 2002.

Felman, Shoshana and Dori Laub. Testimony: Crises of Witnessing in Literature, Psychoanalysis, and History. New York: Routledge, 1992.

Ferejohn, John A., and Pasquale Pasquino. "The Law of Exception: A Typology of Emergency Powers". Int. J Constitutional Law 2 (2004): 210-239.

Fischer, Henry W. Response to Disaster: Fact Versus Fiction and Its Perpetuation. University of America, 1994.

Foster, Hal. The Return of the Real: the Avant-garde at the End of the Century. Cambridge, Mass.: MIT Press, 1996.

Friedrich, Otto. The End of the World: A History. New York: Coward, McCann and Geoghegan, 1982.

Fritz, Charles. "Disasters". Contemporary Social Problems. Eds. Robert K. Merton and Robert A. Nisbet. New York: Harcourt, Brace and World, 1961.

Garrard, Greg. Ecocriticism. London: Routledge, 2004.

Giddens, Anthony. Studies in Social and Political Theory. London: Hutchinson, 1977.

Gifford, Terry. Pastoral. London: Routledge, 1999.

Gross, Oren, and Fionnuala Ní Aoláin. Law in Times of Crisis: Emergency Powers in Theory and Practice. Cambridge: Cambridge University Press, 2006.

Habermas, Jürgen. Theorie des kommunikativen Handelns. Frankfurt am Main: Suhrkamp, 1981.

Heise, Uursula K. Sense of Place and Sense of Planet: the Environmental Imagination of the Global. Oxford: Oxford University Press, 2009.

Holm, Isak Winkel. "Earthquake in Haiti: Kleist and The Birth of Modern Disaster Discourse". New German Critique (no. 115, 2012).

Hulme, Mike. "Four Meanings of Climate Change". Future Ethics: Climate Change and Political Action. Ed. S. Skrimshire. London: Continuum Press, 2010. 
Kant, Immanuel. Critique of the Power of Judgment. New York: Cambridge University Press, 2000.

Kaplan, E. Ann. Trauma Culture: the Politics of Terror and Loss in Media and Literature. Piscataway, N.J.: Rutgers University Press; London, 2005.

Kendrick, T. D. The Lisbon Earthquake. Philadelphia: Lippincott, 1957.

Kermode, Frank. The Sense of an Ending. Studies in the Theory of Fiction. New York: Oxford University Press, 1967.

Klein, Naomi. The Shock Doctrine: the Rise of Disaster Capitalism. London: Allen Lane, 2007.

LaCapra, Dominick. History and Memory after Auschwitz. Ithaca, N.Y.: Cornell University Press, 1998.

- Writing History, Writing Trauma. Baltimore, Md: Johns Hopkins University Press, 2001.

Latour, Bruno. We Have Never Been Modern. Cambridge, Mass.: Harvard University Press, 1993.

Lauer, Gerhard and Thorsten Unger. Das Erdbeben von Lissabon und der Katastrophendiskurs im 18. Jahrhundert. Göttingen: Wallstein Verlag, 2008.

Lazar, Nomi Claire. States of Emergency in Liberal Democracies. Cambridge: Cambridge University Press, 2009.

Lifton, Robert Jay. Superpower Syndrome: America's Apocalyptic Confrontation with the World. New York: Thunder's Mouth Press/Nation Books, 2003.

Lyotard, Jean-François. "The Sublime and the Avant-Garde”. Artforum 22.8 (1984): 36-43.

-. Heidegger and "the Jews". Minneapolis: University of Minnesota Press, 1990.

Mercier-Faivre, Anne-Marie and Chantal Thomas. L'invention de la catastrophe au XVIIIe siècle: du châtiment divin au désastre naturel. Genève: Droz, 2008.

Micale, Mark S. and Paul Lerner. Traumatic Pasts: History, Psychiatry, and Trauma in the Modern Age, 1870-1930. Cambridge: Cambridge University Press, 2001.

Neiman, Susan. Evil in Modern Thought: an Alternative History of Philosophy. Princeton, N.J.: Princeton University Press, 2002.

Neyrat, Frederic. Biopolitique des catastrophes. Paris: Éditions MF, 2008.

Oliver-Smith, Anthony and Susana Hoffman. The Angry Earth: Disaster in Anthropological Perspective. New York: Routledge, 1999.

Picou, J. Steven "Introduction. Katrina as Paradigm Shift: Reflections on Disaster Research in the Twenty-First Century". The Sociology of Katrina: Perspectives on a Modern Catastrophe. Eds. D. L. Brunsma, D. Overfelt and J. S. Picou. Lanham, Md.: Rowman \& Littlefield Publishers, 2007.

Rancière, Jacques. Disagreement: Politics and Philosophy. Minneapolis: University of Minnesota Press, 1999.

Ray, Gene. "Reading the Lisbon Earthquake: Adorno, Lyotard, and the Contemporary Sublime". The Yale Journal of Criticism 17.1 (2004):1-18.

Rozario, Kevin. The Culture of Calamity: Disaster and the Making of Modern America. Chicago: University of Chicago Press, 2007.

Sarat, Austin, Lawrence Douglas, and Martha Merrill Umphrey. Law and Catastrophe. Stanford, Calif.: Stanford University Press, 2007.

Schenk, Gerrit J. Katastrophen: Vom Untergang Pompejis bis zum Klimawandel. Ostfildern: Jan Thorbecke Verlag, 2009.

Schivelbusch, W. Geschichte der Eisenbahnreise: zur Industrialisierung von Raum und Zeit im 19. Jahrhundert. München: Hanser, 1977. 
Sloterdijk, Peter. Schäume, in Sphären. 3. Frankfurt am Main: Suhrkamp, 1998. Taylor, Charles. Philosophical Papers. Cambridge: Cambridge University Press, 1985. —. Modern Social Imaginaries. Durham, N.C.: Duke University Press, 2004.

Tierney, Katheleen, and Christine Bevc. "Disaster as War: Militarism and the Social Construction of Disaster in New Orleans". The Sociology of Katrina: Perspectives on a Modern Catastrophe. Eds. D. L. Brunsma, D. Overfelt and J. S. Picou. Lanham, Md.: Rowman \& Littlefield Publishers, 2007.

Tierney, Katheleen, Christine Bevc, and Erica Kuligowski. "Metaphors Matter: Disaster Myths, Media Frames, and their Consequences in Hurricane Katrina". Annals of the American Academy of Political and Social Science 604 (2006): 57-81.

Virilio, Paul. L'accident originel. Paris: Galilée, 2005.

Wagar, W. Warren. Terminal Visions: the Literature of Last Things. Bloomington: Indiana University Press, 1982.

Walter, François. Catastrophes: une histoire culturelle, XVIe-XXIe siècle. Paris: Seuil, 2008.

Webb, Gary R. "The Popular Culture of Disaster: Exploring a New Dimension of Disaster Research". Handbook of Disaster Research. Eds. H. Rodríguez, E. L. Quarantelli, and R. R. Dynes. New York: Springer, 2007.

Weine, Stevan. M. Testimony after Catastrophe: Narrating the Traumas of Political Violence. Evanston, Ill.: Northwestern University Press, 2006

Welzer, Harald, Hans-Georg Soeffner, and Dana Giesecke. KlimaKulturen: soziale Wirklichkeiten im Klimawandel. Frankfurt am Main: Campus, 2010.

Wojcik, Daniel. The End of the World as We Know It: Faith, Fatalism, and Apocalypse in America. New York: New York University Press, 1997.

Žižek, Slavoj. Some Politically Incorrect Reflections on Violence in France and Related Matters. 3. Escape from New Orleans. lacan.com. 2005. www.lacan.com/ zizfrance $2 . h t m$

-. Welcome to the Desert of the Real: Five Essays on September 11 and Related Dates. London: Verso, 2002.

—. Violence: Six Sideways Reflections. New York: Picador, 2008. 